\title{
MEMES VIRTUAIS E A PERSPECTIVA FUNCIONALISTA DE TRADUÇÃO: CORPUS COMPARÁVEL DO PAR LINGUÍSTICO PORTUGUÊS $<>$ ESPANHOL
}

\author{
Bruna Camila Trombini Schneider \\ Maria José Laiño
}

\begin{abstract}
RESUMO: O meme virtual é um gênero textual/discursivo carregado de elementos verbais, não verbais e culturais. Nascido através da popularização das redes sociais, ele possui conteúdos humorísticos, sarcásticos e reflexivos. Nesse contexto, esse artigo objetiva apresentar um corpus comparativo do gênero meme virtual, bem como refletir e discutir sobre aspectos tradutórios do texto, observando o par português $<>$ espanhol. Os memes utilizados na análise foram encontrados em páginas de redes sociais, em português e espanhol e na análise discutem-se aspectos linguísticos e sua relação direta com os aspectos culturais, assim compreende-se que esses elementos são indissociáveis no processo de tradução. Os pressupostos teóricos deste estudo pautam-se em Marcuschi (2008) e Bakthin (2011), que auxiliam diretamente na discussão sobre os gêneros; Dawkins (2007 [1976]), Souza (2013) e Silva (2016) tratam especificamente sobre o gênero meme. Nord (1994, 2010a e 2010b) elucida a tradução funcionalista, ótica sob a qual são feitas as discussões dos memes ilustrados no trabalho. Com as discussões propostas, percebe-se que a língua é um construto complexo, formado por elementos que superam o campo estritamente linguístico. Isto se torna ainda mais evidente em um processo tradutório, já que há muitas figuras envolvidas e que precisam ser respeitadas, sob a ótica da vertente funcionalista. Nesse sentido, o gênero meme possibilita tal discussão, pois é um gênero que clama por compartilhamento cultural para que atinja um propósito humorístico: neste caso o entrelace entre cultura e língua é feito a partir de um processo comparativo do gênero e das línguas portuguesa e espanhola.
\end{abstract}

PALAVRAS-CHAVE: Gêneros textuais/discursivos. Meme virtual. Teoria funcionalista. Tradução português $<>$ espanhol.

\footnotetext{
* Mestranda em Estudos Linguísticos pela Universidade Federal da Fronteira Sul (UFFS), campus de Chapecó.

${ }^{*}$ Doutora e mestre pela Universidade Federal de Santa Catarina (Ufsc). Professora da Universidade Federal da Fronteira Sul (UFFS). Coordenadora do Programa de Extensão Centro de línguas da UFFS.
} 


\section{Introdução}

Em tempos de uso constante e massivo da internet, não nos damos conta da imensidade de gêneros textuais/discursivos que circulam em nosso cotidiano virtual: recebemos e-mails, enviamos uma notícia a partir de um link de algum site da internet, fazemos compras dos mais diversos setores comerciais, realizamos uma chamada de vídeo para qualquer lugar do mundo, entre outros. Basta que tenhamos um sinal de rede de internet e situações comunicativas acontecem rapidamente.

Nesse sentido, um dos gêneros que se faz presente no dia a dia do internauta brasileiro é o meme virtual. Para além de funções comunicativas, o meme virtual é construído a partir de elementos culturais compartilhados pelos membros da sociedade em que circula, além de elementos verbais e não verbais, que se complementam para compor uma informação. $\mathrm{O}$ meme nasceu através da popularização das redes sociais, bem como sua difusão a partir de conteúdos que levam ao leitor humor, sarcasmo e reflexões acerca de vários temas. Todavia, apesar de reconhecer que o brasileiro tem um senso de humor peculiar e uma criatividade sem fim, o gênero meme, naturalmente, também circula em outras culturas, como na hispânica.

A partir desse contexto, este artigo objetiva fazer um trabalho comparativo, trazendo como corpus o gênero meme virtual, considerando e observando o par linguístico português $<>$ espanhol, realizado à luz da tradutória funcionalista ${ }^{8}$. Nesse sentido, são observadas premissas para além da similitude lexical e estrutural das línguas irmãs: primeiramente, a discussão deste trabalho está pautada em apresentar algumas noções acerca dos gêneros textuais/discursivos, com base em Bakhtin (2011[1992]) e Marcuschi (2008), de forma entrelaçada. Nesse espaço reflexivo, a evolução constante dos gêneros, no que tange

\footnotetext{
${ }^{8}$ Ainda que os memes aqui abordados não sejam traduções, ou seja, não estão em posição de texto fonte e texto meta, pode-se discutir sobre aspectos tradutórios, na medida em que se analisam memes virtuais que têm o mesmo objetivo de interação com o destinatário, e portanto, pode-se pensar em como as diferentes culturas em que circulam esses memes se relacionam com a língua e seus aspectos culturais. Também é interessante pensar que o corpus aqui colocado pode servir como um material comparável para apoio de futuras traduções do gênero.
} 
às novas mídias digitais, também é destacada, assim, o gênero meme virtual é discutido a partir do aporte teórico de Dawkins (2007 [1976]), Souza (2013) e Silva (2016).

$\mathrm{Na}$ sequência, discutimos sobre questões acerca de língua e cultura, trazendo o aporte teórico de Santoyo (1994) e Eco (2007). Sobre tradução funcionalista, nos ancoramos no marco teórico de Nord (1994, 2010a, 2010b). Nesse sentido, para compor um pequeno corpus comparável de análise, foram selecionados dois memes em língua portuguesa e suas possíveis comparações em língua espanhola. Ao final, algumas reflexões são apresentadas, considerando as premissas teóricas e os resultados analíticos realizados.

\section{Os gêneros textuais/discursivos em constante evolução: a ação da tecnologia e os memes virtuais}

Em nosso dia a dia, nas mais diversas atividades que realizamos em nossos espaços das esferas familiar, de estudo e de trabalho, nos deparamos com os mais diferentes gêneros textuais/discursivos: uma conversa ao telefone, um e-mail, um convite para um casamento, o cardápio do restaurante favorito, o dever de casa de matemática dos filhos, um relatório científico, entre tantas infinitas possibilidades.

Essas proposições diárias, que são oferecidas constantemente e na maioria das vezes sem percebermos e refletirmos na medida necessária, fazem parte da necessidade e rotatividade comunicativa que é característica essencial do ser humano. Nesse sentido, a presença constante dos gêneros textuais/discursivos que permeiam a sociedade, como apontam Bergmann e Luckmann (1995, p. 297) à luz de Marcuschi (2008, p. 190), são “[...] um estoque comum de conhecimentos diários sobre normatividade e reputação social da atividade comunicativa [que são] prescritos e moldados pelos gêneros.”.

É válido considerar que, produzidos por meio de uma determinada língua, os gêneros que circulam na sociedade estão ligados aos diversos campos da atividade humana (BAKHTIN, 2011 [1992]). Esta língua não deve ser concebida apenas como um simples código combinado de letras, sons e palavras ou, ainda, não pode ser avaliada de forma 
superficial, ou seja, sem a devida reflexão, descontextualizada e sem considerar sua historicidade, pois se configura como "[...] um fenômeno cultural, histórico, social e cognitivo que varia ao longo do tempo e de acordo com os falantes: ela se manifesta no seu funcionamento e é sensível ao contexto.” (MARCUSCHI, 2008, p. 240).

Por esse viés reflexivo, Bakhtin (2011 [1992]) afirma que cada um dos gêneros abarca não só a temática de seu conteúdo, mas também o estilo de linguagem a ser utilizado e a sua estrutura e construção composicional. Ou seja, observa, inclusive, o uso da língua que se realiza “[...] em forma de enunciados (orais ou escritos) concretos e únicos, proferidos pelos integrantes desse ou daquele campo da atividade humana.” (BAKHTIN, 2011 [1992], p. 261). Ainda, de encontro a tal colocação, Marcuschi (2008) complementa que os gêneros possuem uma estrutura significativa frente a sua realização e materialização na sociedade, mas é a sua função comunicativa que os enaltecem: tais prerrogativas andam lado a lado no que diz respeito à concretude dos gêneros, ou seja, em seu uso na sociedade em que circulam os sujeitos.

Considerando a discussão elaborada, é determinante para os estudos dos gêneros observar a constante evolução da sociedade em que vivemos, bem como a infinidade de gêneros que transpassam o tempo e que se transformam a partir das necessidades comunicativas das pessoas, fazendo com que se modifiquem e passem por metamorfoses a fim de satisfazer os seus usuários:

Se tomarmos o gênero enquanto texto concreto, situado histórica e socialmente, culturalmente sensível, recorrente, 'relativamente estável' do ponto de vista estilístico e composicional, servindo como instrumento comunicativo com propósitos específicos como forma de ação social, é fácil perceber que um novo meio tecnológico, que interfere em boa parte dessas condições, também deve interferir na natureza do gênero produzido (MARCUSCHI, 2008, p. 198)

Destarte, de encontro à perspectiva apontada por Marcuschi (2008), esse estudo também se pauta na afirmativa bakhtiniana de que as possibilidades de uso e criação dos gêneros são inesgotáveis e infinitas, visto a capacidade multiforme da atividade humana, bem como o desenvolvimento e complexidade de determinados campos da sociedade 
(BAKHTIN, 2011 [1992]). É a partir de tal cenário, apontado pelos autores supracitados, que a estabilidade prevalece frente ao uso dos gêneros textuais/discursivos, sendo que as possíveis barreiras estéticas e estilísticas são transpostas a partir da necessidade de uso de novos gêneros, que, de acordo com sua proliferação, surgem e se espalham rapidamente a partir do uso de “[...] novas tecnologias, principalmente na mídia eletrônica (digital)." (MARCUSCHI, 2008, p. 198).

A mídia eletrônica digital, apontada por Marcuschi (2008), engloba, principalmente, a Rede Mundial de Computadores (termo advindo do inglês World Wide Web - o www ao início de um endereço eletrônico), conhecida popularmente como internet ou web. A web é contenedora de uma grande parte dos gêneros possíveis, assumindo, enquanto sistema complexo, uma carga semântica que está em constante aprimoramento e abre portas para que novos gêneros textuais/discursivos revelem-se com rapidez e versatilidade, moldandose às necessidades de comunicação das pessoas.

É nesse espaço e contexto comunicativo que os gêneros passam a sofrer mudanças para se adaptarem ao novo meio: as pessoas passam a enviar menos cartas e se adequam à fluidez e funcionalidade do e-mail, às mensagens eletrônicas e aos chats; os blogs, as revistas e jornais eletrônicos passam a circular como principais fontes de notícias e informações, sendo que esse espaço, anteriormente, era ocupado pelos jornais e revistas impressos; reuniões são marcadas em um local e transmitidas via webconferência para qualquer lugar do mundo, sem a necessidade de estarem todos presentes no mesmo espaço, entre tantos outros exemplos. O resultado de tais mudanças, e que ocorrem em uma velocidade impressionante, é a divulgação de milhares de textos, informações e compartilhamento de dados entre usuários de qualquer parte do mundo (SILVA, 2016).

Um dos gêneros que surge nesse contexto, e que vem ganhando destaque no espaço das mídias sociais, sendo essa a principal difusora e de grande espaço popular em que, segundo Silva (2016, p. 342), há “[...] presença constante de personagens do mundo real proferindo discursos, isto é, interagindo, no ambiente virtual", é o meme virtual. Ele surge na rede a fim de “[...] reproduzir ou representar uma situação ou sentimento de forma 
lúdica ou crítica, com intenção humorística e satírica [...] e pode questionar uma realidade, problematizar uma situação.” (SILVA, 2016, p. 349).

Apesar da propagação do meme virtual acontecer por meio da popularização do uso das redes sociais, principalmente, sua nomenclatura não surge ao acaso: o gênero tem origem no neologismo criado pelo teórico social e estudioso da área da zoologia, Richard Dawkins, na sua obra bibliográfica publicada em 1976, The Selfish Gene (O Gene Egoísta). Dawkins (2007 [1976]), citado por Souza (2013), estabelece uma relação entre a evolução genética e a evolução cultural, a partir de uma grande metáfora:

[... 'A transmissão cultural é análoga à transmissão genética, no sentido de que, apesar de ser essencialmente conservadora, pode dar origem a uma forma de evolução' (DAWKINS, [1976] 2007, p.325). [...] Sendo assim, é possível afirmar que os 'memes' nos utilizam para evoluírem e sobreviverem. Dessa maneira, nós nos tornamos meros hospedeiros das ideias que saltam de cérebro para cérebro as quais estão em constante processo de recombinação e transformação na tentativa de sobrevivência. (SOUZA, 2013, p. 132)

Nesse sentido, o estudioso defende que o termo meme se refere à propagação de elementos culturais de uma pessoa para outra, por instinto de 'sobrevivência', assim como se propagam os genes "[...] pulando de corpo para corpo através dos espermatozoides ou dos óvulos [...]”: os memes propagam-se “[...] pulando de cérebro para cérebro por meio de um processo que pode ser chamado, no sentido amplo, de imitação.” (DAWKINS, 2007 [1976], p. 193 apud SILVA, 2016, p. 343).

Ainda, como forma de justificativa quanto à nomenclatura 'meme', Dawkins (2007 [1976]), citado por Silva (2016), traz à tona a semelhança morfológica com o termo 'gene', bem como relacionada à palavra criada para o conceito de memória, ou, ainda, à palavra francesa même?: "É, pois, por imitação, no sentido amplo, que os memes podem replicarse." (SILVA, 2016, p. 343).

${ }^{9}$ Segundo o dicionário online Linguee, o vocábulo francês même pode ser traduzido para a língua portuguesa como igual, mesmo (LINGUEE, 2019). 
O gênero meme, por ser conceituado como um gênero que se propaga, se replica e se espalha rapidamente, encontra um espaço para 'sobreviver' nas redes sociais mais usadas em nosso contexto, como o Instagram, o Facebook e a aplicativo de conversas instantâneas Whatsapp $p^{10}$. Eles são criados nesses ambientes virtuais, de acordo com Souza (2013), a partir de comentários de uma publicação, postagens de fotos e vídeos, até a criação de paródias que se relacionam a notícias do cotidiano e, a partir de funções particulares, ampliam a intenção de um usuário em específico para outros: é “[...] justamente em razão da replicação do meme, quase sempre de forma viral, sua função se torna socialmente reconhecida, porque agora é compartilhado por um conjunto quase ilimitado de usuários” (SILVA, 2016, p. 349).

Ou seja, os memes se propagam de acordo com o interesse de cada usuário, tornando-se replicadores de ideias, assumindo uma função parecida a dos genes, pois “[...] são egoístas no sentido de que nos utilizarão para que possam ser copiados, sem que haja interesse sobre que efeitos terão sobre seus hospedeiros - só serão transmitidos se possível e conveniente for." (SOUZA, 2013, p. 134).

Por conseguinte, como afirma Silva (2016), a composição do gênero meme pode contar com elementos verbais e não verbais, sendo que sua propagação é extremamente rápida de acordo com uma grande variedade de funções que podem representar, assim como sua rápida replicação através de curtidas e compartilhamentos de acordo com a identificação de cada usuário.

Um exemplo representativo de meme que faz sucesso nas redes sociais usadas por brasileiros, e que apresenta tais características, tem como elemento não verbal a figura de um personagem mexicano, criado por Roberto Bolaños, que ficou famoso no Brasil: o

\footnotetext{
${ }^{10}$ Segundo a revista Exame, em dados de agosto de 2018, o Instagram possui mais de 1 bilhão de usuários ativos no mundo e o Brasil é o segundo país com mais usuários, ranking liderado pelos EUA (EXAME, 2018). Já o Facebook contabilizou 127 milhões de usuários ativos em dados divulgados pela Folha de São Paulo, em Julho de 2018. Em nível mundial, o Brasil está incluso em número de 2,2 bilhões de perfis que acessaram mensalmente até a publicação (OLIVEIRA, 2019). Ainda, o aplicativo Whatsapp, em fevereiro de 2018, possuía 1,5 bilhão de usuários ativos: 120 milhões são brasileiros (GUILHERME, 2018).
} 
Chapolin Colorado. Em um perfil destinado apenas às publicações do@chapolinsincero, nas redes sociais Instagram e Facebook $k^{11}$, o meme virtual faz sucesso quanto às reflexões humorísticas e irônicas que buscam os mais variados contextos e temáticas diárias, assim como apontado por Silva (2016).

O nome dado à página justifica, sugestivamente, o uso dos elementos verbais e não verbais eleitos: o personagem é caracterizado pelo adjetivo ‘sincero' e as orações utilizadas - breves e significativas - propõem, em interação com o leitor, uma brincadeira que mescla elementos linguísticos e culturais, humorísticos e irônicos, impressos através das imagens escolhidas pelo gerenciador dos perfis. As expressões faciais e corporais do personagem principal corroboram com a perspectiva elaborada pelos elementos linguísticos de forma a complementar a informação e interagir com o internauta, como aponta a Figura 1 - Meme Virtual 1, a seguir. Pode-se observar nesta figura a presença de uma frase curta, que é uma das características dos memes virtuais: "POXA FROZEN DÁ UM LERIGOU AIT".

Figura 1 - Meme Virtual 1: Chapolin Sincero "CADÊ A ELSA, TÁ MUITO CALOR"

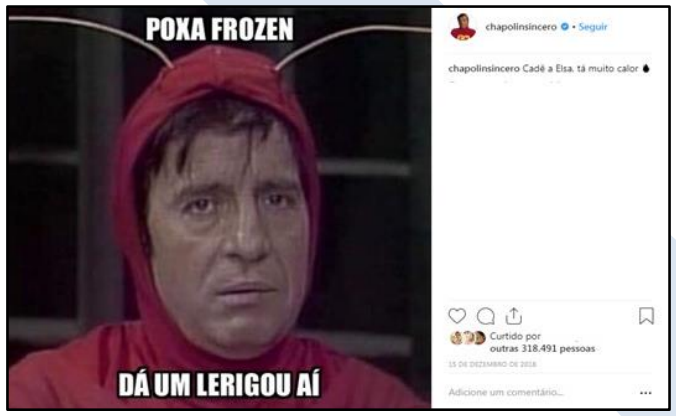

Fonte: https://www.instagram.com/p/BramCd2goRr/ (Acesso em: 15/01/19).

\footnotetext{
${ }^{11}$ O perfil @chapolinsincero é criação do estudante de Publicidade e Propaganda Renan Schwarz (Informação de museudememes.com.br/sermons/chapolin-sincero/). A conta no Instagram - disponível em https://www.instagram.com/chapolinsincero/?hl=pt-br - possui mais de 14,7 milhões de seguidores e mais de 13 mil publicações. Já no facebook - com criação de 22 de agosto de 2012, no endereço https://www.facebook.com/ChapolinSincero/ - o perfil é acompanhado por mais de 7 milhões de seguidores e as publicações ultrapassam as 9 mil postagens. (Dados do acesso em 17/01/2019).
} 
Percebe-se, na composição da sentença utilizada, a informalidade no uso da língua portuguesa, bem como a inserção e uso do vocábulo, referente à forma escrita do inglês "Let it go", que é transformado, a partir de sua realização fonética, em 'lerigou', frase destaque na música tema do filme infantil Frozen, da Disney. Na obra cinematográfica, a personagem principal, a princesa Elsa, possui poderes mágicos que envolvem o frio e a neve, criando castelos de gelo e um inverno profundo.

É nesse contexto que a frase utilizada cria o efeito de humor: em um dia de muito calor no Brasil, dada a publicação ser no mês de dezembro, o criador do meme relaciona as altas temperaturas e intertextualiza com a canção tema do filme infantil, criando um espaço interativo em que locutor e interlocutor estabelecem uma ligação interpretativa. De forma significativa, de encontro e concomitante às premissas do gênero e à oração já descrita, está o elemento não verbal: a feição do personagem Chapolin corrobora com a insatisfação dado o calor excessivo e também a súplica por um clima mais ameno.

A partir de tais características e do exemplo acima mencionado, é válido ressaltar como o usuário das redes sociais consegue fazer uma ponte entre as várias proposições elencadas no meme virtual. Essa interação acontece, principalmente, pela avaliação do usuário da rede social pelo ícone curtir: o meme ilustrado obteve mais de 318 mil curtidas, que funcionam como uma avaliação positiva de interação virtual. Nesse sentido, uma espécie de ressignificação e replicação acontece momentaneamente, abrindo espaço para as interpretações diferenciadas de cada indivíduo e, ainda, confirma o que Marcuschi (2008) aponta acerca dos gêneros e a sociedade que o usam: "[...] sociedades tipicamente orais desenvolvem certos gêneros que se perdem em outras tipicamente escritas e penetradas pelo alto desenvolvimento tecnológico.” (MARCUSCHI, 2008, p. 190). Isto é, os gêneros estão imbuídos de valores que se revelam nas atividades comunicativas de acordo com a época e espaço em que estão inseridos. Assim, a inclusão de elementos diversos no gênero meme, bem como a amplitude e mutabilidade de seu formato, são características constitutivas de sua própria transformação. 
É válido e necessário ressaltar que as escolhas dos elementos utilizados para a criação dos memes virtuais perpassam o uso de apenas imagens e propostas linguísticas. Como apontado, a intertextualidade é recorrente e a interpretatividade exigida com o leitor vai de encontro a elementos culturais que se entrelaçam a todo instante: no caso do meme ilustrado na Figura 1, o personagem Chapolin é familiar aos interlocutores.

\section{Língua e cultura: relação indissociável}

Através do agrupamento dos elementos apontados sobre o meme virtual e, ainda, considerando as vivências e a forma constante em que os gêneros tocam o cotidiano de cada indivíduo, é possível perceber o quanto o construto linguístico e seus elementos culturais estão presentes nas práticas sociais. Assim, é possível apontar que "[...] la idea de cultura vendría a estar asi relacionada con lo individual, local y peculiar de una colectividad humana cualquiera, con características espaciales y temporales bien delimitadas." (SANTOYO, 1994, p. 141).

Nesse viés, Eco (2007) clarifica a afirmação de que língua e cultura são fatores indissociáveis, levando em consideração, e também utilizando como forte argumento, as diferenças que elementos da linguagem possuem através de seu cotejamento entre línguas diferentes, relevando questões culturais diversas em situações aparentemente parecidas:

As palavras coffee, café, caffè [em francês, português e italiano, respectivamente] podem ser consideradas razoavelmente sinônimas só quando se referem a uma certa planta. Mas as expressões donnez-moi un café, give me a coffee, mi dia um caffe (certamente equivalentes de um ponto de vista linguístico, bons exemplos de enunciados que veiculam a mesma proposição, [me dá um café]), não são culturalmente equivalentes. Enunciadas em países diversos, produzem efeitos diversos e referem-se a usos diversos. Elas produzem histórias diversas. (ECO, 2007, p. 197)

Expressões e palavras culturalmente marcadas, como nesse caso a palavra 'café' contextualizada em frases de diferentes línguas, podem oferecer informações sobre o país e a cultura destes locais produzindo histórias diferentes, como bem aponta Eco (2007). O ato de tomar café, mesmo que a planta seja a mesma em qualquer lugar do mundo, não é 
repetível nos diferentes países. Na cidade de Nova York pode-se observar pessoas caminhando apressadas para chegar a um destino segurando um copo de café para levar; já no Brasil, várias famílias sentam em uma mesa para compartilhar esse momento do dia, e isso é extremamente cultural do povo que pratica tais formas de socialização. Assim, uma simples palavra como 'café' pode ser vinculada a situações comunicativas bem distintas que interferem, em menor ou maior medida, em um processo de tradução.

Considerando o exposto que exemplifica a relação de língua e cultura em um contexto específico, é possível perceber que esses dois elementos estão relacionados de forma notável. Ainda, conforme Santoyo (1994), a cultura não está ligada apenas a um elemento único, como as comidas típicas de determinado lugar, mas também a música, os espaços geográfico e climático podem configurar relações culturais perceptíveis a seus usuários, como explícito no meme apresentado na Figura 1 - Meme Virtual 1.

Ponderar as premissas apontadas, em que a cultura está imbricada a uma língua, é afirmar que elas unem-se e configuram-se como um elemento poderoso: “[...] los propios limites espaciales de una cultura coinciden con frecuencia con los de una zona lingüistica, y la mayor parte de las culturas dispone de su propia lengua" (SANTOYO, 1994, p. 147). Nesse âmbito, tais afirmações, quando aliadas às discussões acerca dos mais diversos gêneros textuais/discursivos, nesse caso, a partir do estudo dos memes virtuais, podem ser discutidas juntamente a elementos que unem língua e cultura: o humor cômico.

Nesse sentido, ao considerarmos o exposto, um possível processo de tradução, a Figura 2 - Meme Virtual 2 pode ilustrar como aspectos culturais e situacionais interferem nesse processo que vai além do conhecimento linguístico, lançando ao tradutor alguns desafios que o obrigam a pensar em estratégias específicas para alcançar um efeito cômico no produto traduzido, que é a característica mais presente do gênero meme. 
Figura 2 - Meme Virtual 2: TODOS LOS DÍAS A DIOS LE PIDO

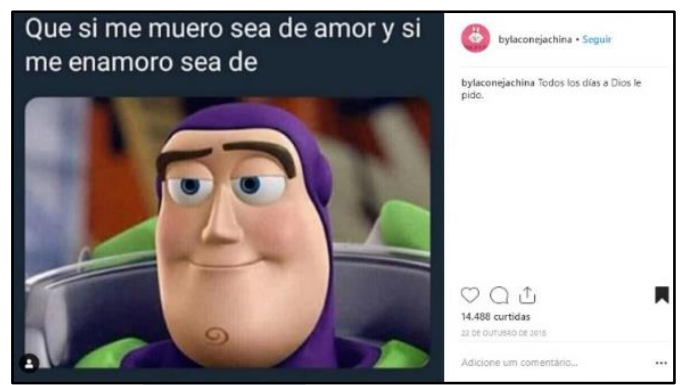

Fonte: https://www.instagram.com/p/BpPP79mlBBY/ (Acesso em: 15/01/2019).

De acordo com a estrutura do meme, que circulou nas redes sociais de usuários da língua espanhola, pode-se observar a presença de uma sentença curta e inacabada, exigindo, dessa forma, que o destinatário interaja com o meme e a complete. A frase proferida "que si me muero sea de amor y si me enamoro sea de" faz referência à música interpretada pelo cantor colombiano Juanes - que, inclusive, compartilhou o meme na sua rede social twitter - e possui a ausência sintática logo ao final. Tal ausência é deixada de lado assim que o interlocutor percebe o elemento não verbal presente no meme. A imagem utilizada é do personagem Buzz Lightyear, protagonista de uma série de desenhos animados da Disney - em Buzz Lightyear e o Comando Estelar, que teve estreia no ano 2000 - e também na sequência de filmes produzidos pela Pixar - Toy Story, que foram aos cinemas pela primeira vez em 1995.

Apesar do contexto infantil representado no meme virtual, o trecho da música utilizado logo retrata a intertextualidade que esse gênero pode utilizar na sua criação e na sua funcionalidade criativa. A expressão facial do personagem cria uma situação e contexto de sedução e romance, o que pode levar a uma das possíveis interpretações do leitor. Essa proposição pode se concretizar quando se percebe a ausência sintática ao final da frase 
proferida, já que a palavra faltante na música seria o pronome pessoal $\operatorname{vos}^{12}$ que, nesse contexto, a partir da produção fonética em língua espanhola, soa parecido com o nome do personagem retratado na imagem (Buгz).

Se pensarmos em uma tradução deste meme, considerando o par linguístico espanhol $<>$ português, certamente encontraríamos barreiras culturais e linguísticas no processo tradutório. Apesar da música citada possuir uma versão na língua portuguesa e os brasileiros conhecerem o personagem apresentado, a barreira interpretativa estaria no jogo linguístico usado no meme original. Na versão em língua portuguesa, a canção possui nesse espaço sintático também um pronome, mas esse não ocupa um espaço de pronome pessoal, mas sim de possessivo - seu ${ }^{13}$. Considerando a ausência escrita de pronome na versão original, lacuna essa suprida pelo elemento não verbal, podemos perceber que não há proximidade de pronúncia entre Buzz e seu, como foi feito com os elementos verbais e nãoverbais em espanhol. Mesmo com uma adaptação para um pronome pessoal como você ou tu, a tradução literal não contemplaria o público alvo, já que o complemento está no elemento não verbal, ou seja, na figura ilustrativa de Buг:.

Nesse caso, percebe-se como é importante e determinante para o sucesso tradutório que se faça uma análise do texto base e se compreenda todos os seus sentidos para posteriormente fazer a tradução e refletir sobre o efeito desta no público destinatário da cultura base. A língua, portanto, não deve ser entendida como uma simples cadeia de palavras, já que outros elementos são importantes na elaboração do meme, como a criatividade do emissor, a sua intenção e o efeito que este deseja causar. Sobre a pluralidade linguística, Marcuschi (2008, p. 241) afirma que “[...] a língua é semanticamente opaca, e os textos

\footnotetext{
12 Trata-se do pronome de segunda pessoa do singular utilizado na língua espanhola e que tem como característica o uso em contextos de tratamento informal. Este pronome é usado no espanhol da América Latina e, em uma tradução para língua portuguesa, ele poderia ser traduzido para $t u$ ou você, dependendo do contexto geográfico e situacional de seu proferimento. É válido ressaltar ainda que, a partir do uso de tal pronome, perceba-se que o meme foi criado para circular em um espaço geográfico que use o vos como segunda pessoa do discurso, o que não impede que ele circule em outras culturas.

13 "E se eu morrer que seja de amor e que o meu amor seja todo seu". Música A Deus eu peço. Artista: Alexandre Pires. Ano de lançamento: 2005.
} 
podem produzir mais de um sentido. A língua permite a pluralidade e significações e as pessoas podem entender o que não foi pretendido pelo falante ou autor do texto.”.

Ao considerarmos o exposto, vemos nos processos comunicativos e tradutórios uma dificuldade que a tradução evidencia: cada língua possui elementos linguísticos e semióticos que podem estabelecer inúmeras relações com as diferentes culturas e situações possíveis. Fica claro o quanto todos esses elementos são importantes em um processo tradutório e não podem ser desconsiderados, assim como apontam as premissas da tradução funcionalista, da teórica alemã Christiane Nord (1994, 2010a, 2010b), as quais são discutidas a seguir.

\section{A tradução funcionalista de Christiane Nord: premissas para além da língua}

Ao nos depararmos com um texto traduzido esperamos que o Texto Base (TB) tenha sido respeitado quanto ao seu conteúdo e tenha sido traduzido ao Texto Meta (TM) de forma que o seu destinatário tenha sido colocado em prospecção pelo tradutor. Todavia, essa tarefa não é tão simples, já que o tradutor precisa estar ciente que está lidando com aspectos que perpassam o campo da estrutura linguística, ou seja, que ultrapassam o campo do concreto.

A teoria de tradução que abarca as preocupações acima citadas é a funcionalista, especificamente o funcionalismo alemão. Defendida, teorizada e conduzida pelas reflexões da teórica Christiane Nord, inspirada em Reiss e Vermeer, sua teoria reflete acerca das propostas do funcionalismo tradutório, pautada na teoria do Skopos (Skopostheorie: propósito, motivação). Nesse sentido, Nord afirma que a teoria funcionalista de tradução defende que o produto tradutório, o TM, "[...] depende del fin u objetivo [...] que debe cumplir el texto terminal en la cultura meta. Uno de los factores principales que determinan el objetivo de una traducción es el receptor o destinatario del texto meta." (NORD, 1994, p. 99). Ou seja, considerar o público alvo no processo de tradução é de suma importância para essa vertente, pois impacta diretamente nas decisões tradutórias e pode mudar o rumo da tradução. 
Ao falar sobre tradução, entram em pauta os conceitos de equivalência e fidelidade, que adquirem diferentes formas de acordo ao marco teórico que se enquadra o tradutor. Segundo Nord (1994), o conceito de equivalência tradutória sempre foi alvo de ambiguidades e distintas interpretações, mas que, de acordo com a autora, poderia ter uma definição a partir do significado etimológico da palavra: “[...] 'equivalencia' algo así como 'igualdad de valores', refiriéndonos a los valores semánticos, estilísticos y pragmáticos de un texto." (NORD, 1994, p. 97).

Segundo a igualdade de valores apontada por Nord (1994), a equivalência em tradução pode aparecer em diferentes instâncias, como apontado abaixo pela autora:

a. Igualdad de valores pragmáticos: El TO [Texto Original] y el TM son equivalentes si tienen la misma función y el mismo valor o efecto comunicativo y si van dirigidos al 'mismo' grupo de receptores;

b. Igualdad de valores lingüisticos-estilisticos: el TM es equivalente al TO si 'imita' o 'refleja' su forma o 'muestra su belleza';

c. Igualdad de valores semánticos: el TO y el TM son equivalentes si tienen el mismo 'significado' $y$ / o transmiten el mismo 'mensaje'. (NORD, 1994, p. 97)

A partir das relações expostas por Nord, pode-se perceber que a tradução de um texto vai além de aspectos meramente linguísticos: no âmbito da teoria de tradução funcionalista os entremeios culturais das línguas envolvidas e os valores semânticos são fatores determinantes para guiar uma tradução. Nesse sentido, como bem aponta Nord (1994), ao traduzir um determinado texto, o tradutor deve considerar as relações criadas entre a cultura e língua de partida, refletir acerca dos valores pragmáticos e linguísticos, e ainda, confirmar que,

[... 'el significado' de un texto no es sólo la suma de los contenidos semánticos de sus elementos (palabras, estructuras sintácticas, prosodia, composición textual, etc), sino más bien el resultado de la interdependencia entre la forma y el contenido de los elementos textuales, por una parte, y su función o funciones comunicativas, por otra. Se podría decir que el pontecial semántico del texto 'canaliza' hacia un significado determinado mediante la función textual. (NORD, 1994, p. 102) 
Esse construto, apontado por Nord, é perceptível quando se trata da tradução de gêneros textuais/discursivos que devem se aproximar de seu público destinatário para alcançar seu propósito comunicativo. Este seria o caso do gênero meme, que se insere em um contexto situacional em que a troca entre locutor e interlocutor é essencial para a comunicação acontecer de forma completa, conforme podemos verificar no exemplo da Figura 3 - Meme Virtual 3, a seguir.

Figura 3 - Meme Virtual 3: Chapolin Sincero "SAINDO DE CASA"

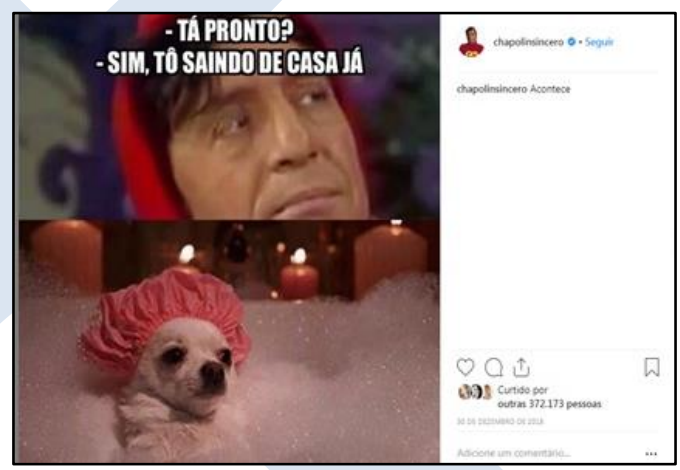

Fonte: https://www.instagram.com/p/BsBZTPqgPEJ/ (Acesso em: 15/01/19)

Com mais de 372 mil curtidas, o meme virtual exposto na Figura 3 é composto pelo personagem que intitula a página, mas também há a presença, através da divisão da imagem, de um novo personagem, um cachorro tomando banho. No primeiro plano, junto à imagem do Chapolin, há um diálogo entre duas pessoas, esse representado pelo uso do signo de pontuação travessão.

Embora ocorra a economia linguística nesse meme - está/tá e estou/tô -, muito comum na realização informal e oralizada da língua, o humor está na imagem que completa a parte inicial: um cachorro, com touca de banho, em uma banheira de espumas e com velas ao fundo. Em uma proposta comparativa desse meme, poderíamos assumir como versão em língua espanhola a Figura 4-Meme Virtual 4: 
Figura 4 - Meme Virtual 4: "TIPICO DE SABADO”

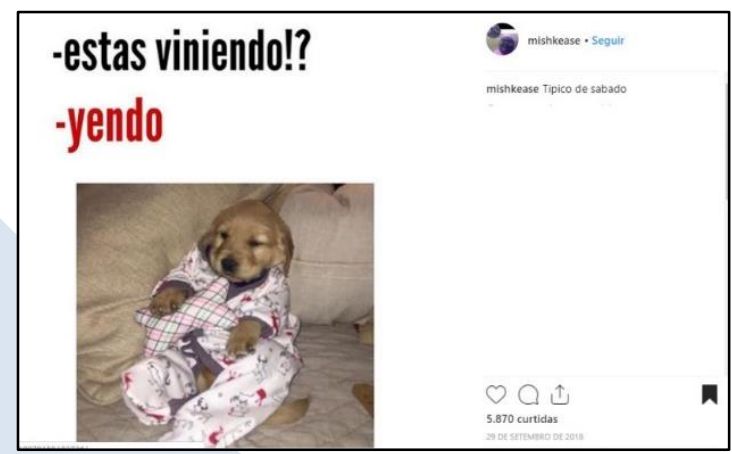

Fonte: https://www.instagram.com/p/BoVAmVFH_jN/ (Acesso em: 15/01/19).

Apesar de não haver a presença do personagem Chapolin Colorado no meme da Figura 4, como no meme anterior, podemos perceber as intenções e interpretações possíveis por parte do interlocutor de maneira aproximada. Nesse caso, novamente há um diálogo na mesma configuração do meme em português com frases curtas e informais.

Vimos que, na língua portuguesa, a redução dos vocábulos diminuiu para a forma escrita, assim como a forma oralizada permite - redução de 'está' para 'tá' e 'estou' para 'tô'. Nesse caso, em espanhol, percebemos a ausência dos signos de pontuação que indicam interrogação e exclamação logo ao início de uma frase, como vem ocorrendo em situações comunicativas escritas informais, assim como acontece também na língua portuguesa.

Embora não comprometa o entendimento do interlocutor, a ausência de tais pontuações podem indicar a interação do meme e seus usuários, bem como ampliam a visão de que os gêneros não são imutáveis, ou seja, necessariamente ficariam estagnados a uma estrutura verbal e não verbal fixa, como podemos ver através da imagem utilizada: novamente temos um cão como representante das ações possíveis, sendo que este encontra-se em um sofá, usando um pijama. 
Em um processo de comparação dos memes, podemos perceber que o meme da Figura 3 tem a intenção de afirmar que o indivíduo que pergunta se o outro está pronto vai ter que aguardar um tempo, uma vez que o cachorro está no banho, sem maiores preocupações com o horário do compromisso. Já na Figura 4, embora outras interpretações de cunho pessoal possam surgir, pode-se ainda haver como atribuição interpretativa de maneira compartilhada, ou seja, de modo comum, o fato de não ir ao compromisso marcado, já que o personagem se encontra em vestimentas para dormir.

A partir de um viés analítico, considerando elementos culturais, é difícil encontrarmos em um ambiente externo ao de uma residência, alguém de pijama presumindo que, para sair para algum lugar, tomar um banho é algo rotineiro, mas não com touca, sais de banho e velas. Tais simbologias evidenciam ao leitor que, em ambas as Figuras - 3 e 4 -, a resposta dada aponta que o questionador precisará esperar mais do que imagina, já que não há pressa e nem pretensão total para sair do banho ou tirar o pijama.

Num contexto comparativo entre esses memes, poderíamos afirma que existe uma “[...] igualdad de valores pragmáticos y valores lingüisticos-estilísticos [...]” como apontado por Nord (1994, p. 97), já que existe um reflexo na forma entre os memes do par linguístico português $<>$ espanhol. Pela mesma linha de averiguação teórica e analítica, as premissas nordianas acerca da “[...] igualdad de valores semánticos [...]" (NORD, 1994, p. 97) não se confirma frente aos memes analisados, já que a interpretação a nível semântico, através das imagens utilizadas, será feita de acordo com cada leitor/interlocutor.

Por esse contexto, Nord (2010a, p. 241) aponta que serão "[...] los receptores los que decidirán sobre la funcionalidad de un texto (y también de la traducción).”. Nesse espaço, empregar “[...] 'marcadores funcionales' lingüísticos y extralingüísticos” (ibid) configura-se como algo ideal para uma boa tradução, ou seja, para que a mensagem do texto seja compreendida de acordo com a língua em que irá circular sem ignorar a cultura que está imbricada a ela.

Por seu conteúdo humorístico, o bilhete ilustrado abaixo (Figura 5 - Meme Virtual 5) foi transformado em meme. A nota foi escrita por uma criança em fase de alfabetização, sendo que sua repercussão nas redes sociais foi imediata, logo após a professora e a mãe 
da criança exporem a criatividade e inocência infantil em criar um bilhete falso de que não haveria aula na escola em que estuda.

Figura 5 - Meme virtual 5: É VERDADE ESSE BILETE

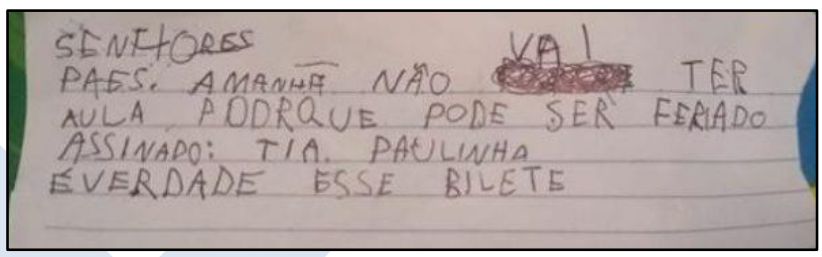

Fonte: https://www.dicionariopopular.com/e-verdade-esse-bilete/ (Acesso em: 19/01/19).

Podemos perceber que se trata de um bilhete escrito a mão por um indivíduo que ainda está no aprimoramento de sua habilidade escrita, ao perceber o uso de letras maiúsculas, uma rasura e erros de ortografia: paes, poorque, e bilete - pais, porque e bilhete, respectivamente. Apesar da ingenuidade infantil ao escrever o bilhete, bem como a presença/ausência de alguns elementos linguísticos para tornar a informação verídica, o que se tornou cômico foi o fato de uma mentira visível tentar ser refutada pela frase ao final: 'É VERDADE ESSE BILETE'

Ao observarmos tais características, nota-se a versatilidade do gênero meme já que, ao contrário dos memes apresentados anteriormente neste estudo, este não apresenta elementos não verbais. Percebe-se, então, a flexibilidade comunicativa e interativa desse gênero, deixando a criatividade a rigor dos criadores, usuários e interlocutores do gênero.

Outro fato a ser averiguado é a replicação imediata desse meme: rapidamente, outros memes foram criados a fim de interagir com as mais variadas temáticas, interlocutores e usuários da internet. Embora a criação de outros memes tenha acontecido em tempo recorde, a temática continuou a mesma e foi utilizada até como estratégia de marketing: uma mentira evidenciada a partir da frase padrão final (Figura 6 - Meme Virtual 6). 
Figura 6 - Meme virtual 6: É VERDADE ESSE BILETE Marketing Netflix

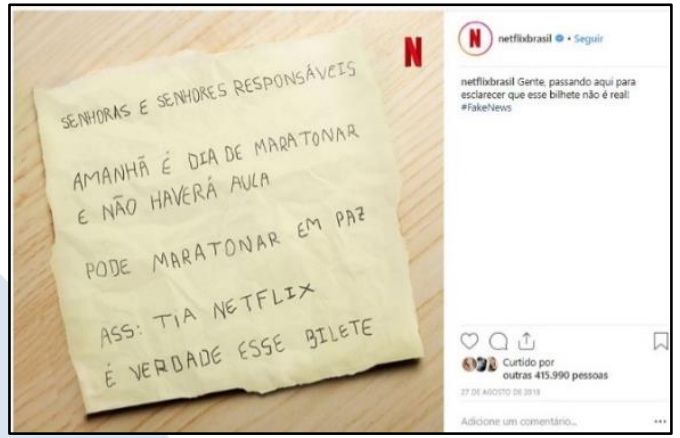

Fonte: https://www.instagram.com/p/Bm_m571H123/?utm_ source=ig_embed (Acesso em: 31/01/19)

Considerando o exposto, uma versão em língua espanhola também circulou atendendo as mesmas premissas do 'bilete' criado em um contexto comunicativo escolar (Figura 7 - Meme Virtual 7):

Figura 7 - Meme Virtual 7: é verdade esse bilete, possível versão em língua espanhola.

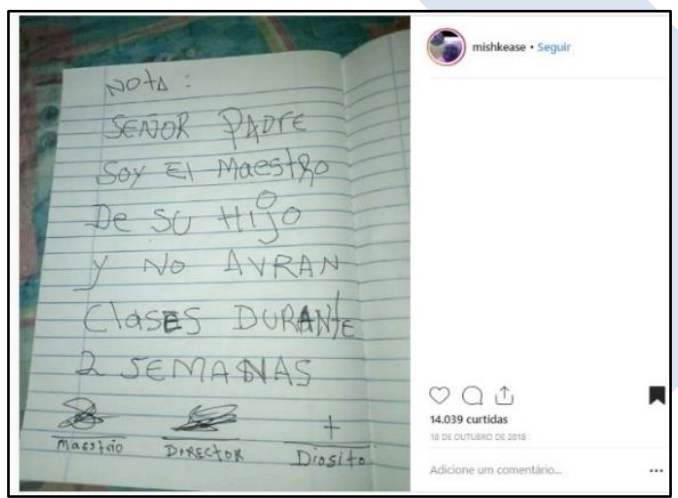

Fonte: https://www.instagram.com/p/BpFzo8fnJ8L/ (Acesso em: 15/01/19) 
A versão apresentada em espanhol é composta por um bilhete escolar que, em um processo de propagação e replicação constante, se apresenta como meme. Nesse meme podemos observar os equívocos ortográficos semelhantes aos apresentados na Figura 5: havran, ao invés de habrán; maestrio, no lugar de maestro. Em contrapartida, ao final do bilhete a criança cria assinaturas falsificadas de pessoas ligadas ao contexto e que são usadas para darem credibilidade à informação: el maestro - o professor -, el director - o diretor - e, pelo viés religioso para parecer verdade absoluta, Diosito - Deusinho, assinado por uma cruz.

Cotejando as versões em língua portuguesa e em língua espanhola, podemos perceber que nessas propostas não há a presença linguística da mesma frase apresentada no meme em língua portuguesa: 'é verdade esse bilete'. Todavia, essa ausência é substituída pelo campo de assinaturas de autoridades escolares e religiosas. Ainda, podemos observar que entre os memes do par linguístico existe uma equivalência, apontada por Nord, na qual, em um processo de tradução, se considera a "igualdad de valores semánticos” (NORD, 1994, p. 99) como uma proposta possível e assertiva em que se realizará o processo comunicativo: a mensagem tanto na língua portuguesa (Figura 5), como na língua espanhola (Figura 7) é transmitida de forma equivalente.

Nesse contexto, em um processo tradutório, as culturas que permeiam tanto o TB como o TM precisam confrontar-se, a fim de saltar barreiras culturais que perpassam o campo do concreto. Nos memes das Figuras 5 e 7, percebemos que a presença da frase 'É VERDADE ESSE BILETE' e a ausência dela ocupada pelo espaço da falsificação das assinaturas, respectivamente, preenchem um espaço interpretativo de equivalências. O que acontece, nesse caso, é o salto da barreira cultural - valla cultural ${ }^{4}$ - exposta entre os textos, como aponta a Figura 8, em que relações intertextuais precisam ser analisadas para que, no

\footnotetext{
${ }^{14}$ Valla cultural é definida por Nord (2010b) como uma barreira cultural entre os textos fonte e meta. Essa barreira pode ter um efeito negativo no que se refere à compreensão do texto meta pelo público destinatário da tradução. $\mathrm{O}$ tradutor, portanto, precisa compreender quais seriam os pontos de conflito entre os contextos de ambos os textos envolvidos no processo de tradução e fazer as adaptações necessárias, sempre de acordo com o encargo de tradução.
} 
processo tradutório, diminua-se o impacto significativo entre as línguas e, de forma concomitante, as culturas distintas.

Figura 8: A barreira - valla - cultural segundo a teoria funcionalista de tradução

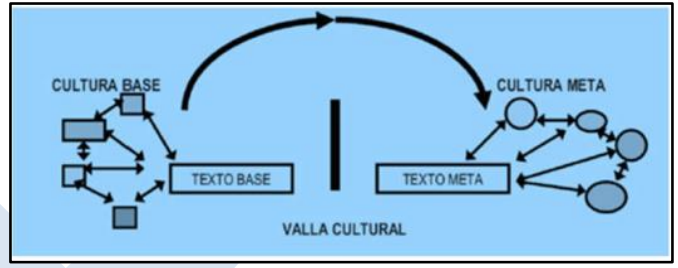

Fonte: NORD, 2010b, p. 11.

Assim, ao observarmos as equivalências entre o português e o espanhol, considerando constantemente os elementos culturais que permeiam as práticas discursivas de seu uso, Nord (2010b) aponta e afirma que o propósito comunicativo deve ser mais um dos destaques na prática tradutória: indiferente do propósito, um texto traduzido deve estar no repertório da cultura meta e "[...] se espera que este nuevo texto sea conforme con las normas de una clase o un género textual especifico o que represente ciertas características temporales o de registro" (NORD, 2010b, p. 11).

Destarte, as premissas apresentadas na Figura 5, a partir da frase que viralizou nas redes sociais dos brasileiros, criou um vínculo cultural a partir de uma situação específica daquela comunidade em que circulou o bilhete: em um caso de tradução literal, ou palavra por palavra, o tradutor poderia tornar-se um traidor, já que o propósito comunicativo ultrapassa o formato sintático da frase "É VERDADE ESSE BILETE". Nesse caso, em uma proposta realizada na língua espanhola, o propósito comunicativo poderia ser atingido, mas, possivelmente, não com a mesma proporção que aconteceu no contexto brasileiro.

\section{Considerações finais}

Além do que foi abordado até o momento, é preciso ressaltar e considerar, assim como as discussões acerca dos gêneros textuais/discursivos que vêm sendo tratadas desde 
a década de 60 pela ótica da linguística de texto e a análise conversacional, como observa Marcuschi (2008), o estudo e a análise desses novos gêneros que surgem constantemente é feito. Nesse sentido, deve-se levar em conta, o espaço em que os gêneros circulam, bem como seus usuários e sua visível ascensão.

Portanto, justificamos como relevante fazer um estudo, ainda que breve e ilustrativo, do gênero meme virtual, por se tratar de um gênero ainda em ascensão e que abarca os pressupostos teóricos de Marcuschi (2008): (i) os gêneros se desenvolvem rapidamente e possuem uma fase de fixação com uso generalizado; (ii) eles apresentam peculiaridades próprias mesmo tendo parte de gêneros prévios; (iii) a partir dos gêneros é possível rever conceitos tradicionais de textualidade; e (iv) é através deles que a oralidade e escrita obrigam os interlocutores a repensarem seu uso e a relação entre ambas.

Os memes têm a potencialidade de mudar sensivelmente a relação com a escrita e, por ser um gênero curto com muitos elementos não verbais, bem como a possibilidade de intertextualidade com outros gêneros, atrai o destinatário, que se sente contemplado com a mensagem, compartilhando a informação de maneira disseminada e rápida.

Entendemos que pelo fato de haver uma proximidade linguística entre as línguas portuguesa e espanhola, no momento da tradução pode ser que haja uma falsa sensação de equivalência, tanto linguística como cultural e semântica. No entanto, apesar de próximas, essas línguas estão separadas também por aspectos culturais e geográficos, o que influencia diretamente na relação que os sujeitos mantêm com a língua em uso, bem como a presença e intencionalidade humorística que também estão presentes nos memes virtuais exemplificados e analisados nesse estudo.

Tal construto corrobora com a afirmação de que os memes utilizam elementos verbais e não verbais em sua estrutura composicional, e ainda envolvem elementos além do cunho linguístico das línguas envolvidas em um processo de análise tradutório: a cultura se faz presente a partir das diferentes comunidades linguísticas que apresentam diferenças do que consideram cômico, jocoso ou humorístico. As pessoas se divertirão a partir de gatilhos distintos, de acordo com o funcionamento de sua própria sociedade. 
Nesse sentido, a teoria funcionalista de tradução foi escolhida - através de uma análise de equivalência na igualdade de valores pragmáticos, linguísticos-estilísticos e também semânticos -, propondo um recorte reflexivo nesse estudo, por compreender que esta valoriza os elementos culturais em conjunto com os elementos linguísticos de ambas as línguas/culturas envolvidas. Ainda, tal proposta de análise e reflexões tradutórias também considera como determinante aquele que vai entrar em contato com o TM e dar sentido àquela mensagem, ou seja, o público destinatário: entende-se, então, que os gêneros devem funcionar na comunidade em que circulam, se este for o ou um dos objetivos da tradução.

\section{MEMES VIRTUALES Y LA PERSPECTIVA FUNCIONALISTA DE TRADUCCIÓN: CORPUS COMPARABLE DEL PAR LINGÜÍSTICO PORTUGUÉS<> ESPAÑOL}

RESUMEN: El meme virtual es un género textual/discursivo cargado de elementos verbales, no verbales y culturales. Nacido a través de la popularización de las redes sociales, tiene contenido humorístico, sarcástico y reflexivo. En este contexto, este artículo tiene como objetivo presentar un corpus comparativo del género meme virtual, así como reflexionar y discutir sobre los aspectos de traducción del texto, observando el par portugués $<>$ español. Los memes utilizados en el análisis se encontraron en las páginas de redes sociales, en portugués y español, y el análisis discute aspectos lingüísticos y su relación directa con aspectos culturales, entendiendo que estos elementos son inseparables en el proceso de traducción. Los supuestos teóricos de este estudio se basan en Marcuschi (2008) y Bakthin (2011), que ayudan directamente en la discusión sobre los géneros; Dawkins (2007 [1976]), Souza (2013) y Silva (2016) tratan específicamente del género meme; y Nord (1994, 2010a y 2010b) aclara la traducción funcionalista y óptica bajo la cual se realizan las discusiones de los memes ilustrados en el documento. Con las discusiones propuestas, queda claro que el lenguaje es una construcción compleja, formada por elementos que superan el campo estrictamente lingüístico. Esto se hace aún más evidente en un proceso de traducción, ya que hay muchas figuras involucradas y que deben ser respetadas, desde la perspectiva funcionalista. En este sentido, el género meme permite tal discusión, ya que es un género que requiere el intercambio cultural para lograr un propósito humorístico: en este caso, el entrelazamiento entre cultura e idioma se realiza a partir de un proceso comparativo del género y los idiomas portugués y español.

PALABRAS-LLAVE: Géneros textuales/discursivos. Meme Virtual. Teoría funcionalista. Traducción portugués $<>$ español.

\section{REFERÊNCIAS}

BAKHTIN, M. Estética da criação verbal. Trad. Paulo Bezerra. 6. ed. São Paulo: Martins Fontes, 2011. 
EXAME. Instagram, 15 vezes mais interações que outras redes sociais. 2018. Disponível em: https://exame.abril.com.br/negocios/dino/instagram-15-vezes-mais-interacoes-que-outras-redes-sociais/. Acesso em: 17 jan. 2019.

GUILHERME, Paulo. 1,5 bilhão: esse é o número de usuários ativos mensais do WhatsApp. 2018. Disponível em: https://www.tecmundo.com.br/software/126769-1-5-bilhoes-numero-usuarios-ativos-mensais-whatsapp.htm. Acesso em: 17 jan. 2019.

LINGUEE: Dicionário francês-português e buscador de traduções. Disponível em: https://www.linguee.com.br/portugues-frances/search?source=frances\&query $=\mathrm{m} \% \mathrm{C} 3 \%$ AAme. Acesso em: 06 fev. 2019.

MARCUSCHI, Luiz Antônio. Produção textual, análise de gêneros e compreensão. São Paulo: Parábola Editorial, 2008. 298p.

NORD, Christiane. Traduciendo Fuciones. In: ALBIR. A. H. Estudis sobre la Traducció. Castellón: Universitat Jaume I. 1994, p. 97-112.

NORD, Christiane. Las funciones comunicativas en el proceso de traducción: un modelo cuatrifuncional. In: Núcleo. no. 27. 2010a.

NORD, Christiane. La intertextualidad como herramienta en el proceso de traducción. In: Puentes, Granada, n. 9, p. 9-18, março 2010b.

OLIVEIRA, Felipe. Facebook chega a 127 milhões de usuários mensais no Brasil. 2018. Disponível em: https://www1.folha.uol.com.br/tec/2018/07/facebook-chega-a-127-milhoes-deusuarios-mensais-no-brasil.shtml. Acesso em: 17 jan. 2019.

SANTOYO, J.C. Traducción de cultura, Traducción de civilización. In: ALBIR. A. H. Estudis sobre la Traducció. Castellón: Universitat Jaume I. 1994, p. 141-152.

SILVA, A. A. Memes virtuais: gêneros do discurso, dialogismo, polifonia e heterogeneidade enunciativa. Travessias (UNIOESTE. Online), v. 10, p. 341-361, 2016.

SOUZA, C. F.. Memes: formações discursivas que ecoam no ciberespaço. Vértices (Campos dos Goitacazes), v. 15, p. 127-148, 2013.

Recebido em: 29/08/2019. Aprovado em: 22/10/2019. 